Joanna Swędrak*

Lublin

\title{
Model życia współczesnej rodziny
}

\section{Wprowadzenie}

Rodzina od najdawniejszych czasów zajmowała uwagę filozofów, a także reformatorów życia społecznego. Już Arystoteles podejmował próby teoretycznej analizy życia rodziny oraz jej miejsca w społeczeństwie. Księgi Starego i Nowego Testamentu również pełne są obrazów, porównań, przykładów i wskazówek moralnych dotyczących małżeństwa oraz życia rodzinnego. Biblia zatem stanowi dotąd źródło i fundament klasycznej, podstawowej wspólnoty, która jest najstarsza i najpełniej angażuje człowieka.

Polskimi prekursorami badań nad rodziną byli Florian Znaniecki oraz Bronisław Malinowski. Natomiast w latach międzywojennych Ludwik Krzywicki i Józef Chałasiński podjęli próby pierwszych publikacji, których wyniki badań odzwierciedlają obraz polskiej rodziny chłopskiej. Nie można pominąć tutaj również Karola Wojtyły, który rozważania na temat miłości małżeńskiej i rodziny zawarł w swoich wykładach z etyki.

Podejmowaniu badań nad tematyką rodzinną sprzyja traktowanie rodziny jako grupy społecznej, zabezpieczającej ciągłość biologiczną społeczeństwa. Etymologicznie słowo „rodzina” wypływa z pojęcia „rodzenia” (Jakubiak, 1995). Dlatego też można stwierdzić, iż podstawą istnienia jest rodzenie potomstwa, bądź przysposobienie go czy adopcja. Drugim czynnikiem jest chęć przekazu nagromadzonego dorobku kulturowego w ramach utrzymania i ocalenia własnej tożsamości.

W ostatnich latach zauważyć można wzrastające zainteresowanie zarówno historią tematyki rodzinnej, jak i jej współczesnym obliczem. Być może wiąże

* Mgr Joanna Swędrak, uczestnik studiów doktoranckich w Instytucie Pedagogiki i Psychologii Uniwersytetu Marii Curie-Skłodowskiej w Lublinie. 
się to z niewątpliwym kryzysem przeżywanym obecnie przez wiele polskich rodzin. Badacze być może wyrażają nadzieję, że dzięki badaniom łatwiej będzie wyciągnąć właściwe wnioski budujące związki rodzinne, stanowiące fundament przyszłego społeczeństwa.

Rodzina odgrywa ogromną rolę w życiu człowieka i jest uznawana za element jej rozwoju. Powinna być źródłem wzajemnej miłości, szacunku i solidarności. Jednak w chwili obecnej polskiej rodzinie przypadło funkcjonować w bardzo trudnym czasie. Zachwiana została hierarchia wartości, tak żmudnie budowana przez stulecia, pogorszył się poziom materialny wielu rodzin, rozluźnieniu uległy normy etyczne i moralne, a także więzi emocjonalne między jej członkami.

Ogromnym zagrożeniem dla rodziny jest bezrobocie, rozłąki zagraniczne małżeństw, liberalizacja związków i poglądów etycznych. Wielu ludzi żyje w bardzo trudnej sytuacji, w dramatycznych warunkach, dlatego też narasta w nich poczucie bezradności i krzywdy, co niewątpliwie ujemnie wpływa na ogólne funkcjonowanie rodziny. Załamują się wtedy hierarchie wartości i wspólne więzi. Rodziny znajdujące się w sytuacji ubóstwa wymagają pomocy z zewnątrz, natomiast tym na granicy ubóstwa pieniędzy wystarcza tylko na podstawowe wydatki i opłacenie świadczeń (Cudak, 2000).

Niedostatek finansowy przeżywają również rodziny z problemem alkoholowym, a takich niestety jest wiele w naszym społeczeństwie. Nadużywanie alkoholu prowadzi do zanikania więzi uczuciowych i emocjonalnych, u dzieci wywołuje frustrację i poczucie krzywdy. Przeżycia i doświadczenia dziecka w rodzinie alkoholika pozostawiają trwały ślad w psychice i przyszłym, dorosłym życiu (Kryczka, 1997).

Ostatnie badania wykazały również, że w rodzinach bardzo często dochodzi do wzajemnej przemocy: fizycznej, seksualnej, psychicznej. Takie zachowanie godzi w życie, w integralność psychiczną i fizyczną, w wolność członków rodziny (Badura-Madej, 2000).

Zjawiska patologii społecznej wpływają na dysfunkcyjność rodziny, co prowadzi do niezaspokojenia silnie odczuwanych potrzeb miłości i przynależności, bezpieczeństwa, opieki, oparcia i wolności.

Również bardzo niepokojącym zjawiskiem w każdej rodzinie są konflikty małżeńskie, u których podłoża leżą różnice temperamentu, oziębłość płciowa jednego z małżonków, brak satysfakcji z pożycia seksualnego, ponieważ nie da się oddzielić sfery seksualnej od zharmonizowania uczuciowego partnerów. Także brak zaspokojenia potrzeb ekonomicznych, zawieranie małżeństw przedwcześnie, rozczarowania wynikające z niespełnienia wzajemnych oczekiwań to tylko niektóre z przyczyn konfliktów (Cudak, 2000).

Utrata pracy jest równoznaczna $\mathrm{z}$ pogorszeniem się sytuacji materialnej rodziny, a niejednokrotnie oznacza ubóstwo, zmiany w ekonomicznej i społecznej kondycji. Sytuacja materialna rodziny bezrobotnej uzależniona jest od wielu czynników, między innymi: czasu, w jakim członek rodziny pozostaje bez pracy, liczby osób niepracujących w rodzinie, wykształcenia, jakie posiadają bez- 
robotni, struktury rodziny, itp. (Dymara, 1998). Większość osób bezrobotnych jest $\mathrm{w}$ wieku aktywnego rodzicielstwa, dlatego też skutki utraty pracy dotyczą wszystkich członków rodziny. W związku z tym utrata pracy może być przyczyną: zmian form opieki nad dziećmi, zmian planów dotyczących edukacji dzieci, nabycia poczucia niskiej samooceny i ograniczenia kontaktów środowiskowych, w końcu konfliktów i napięć między małżonkami (Danielewicz, 2001).

Wiele polskich rodzin na skutek ich dysfunkcyjności wymaga wsparcia z zewnątrz: wsparcia psychologicznego, pedagogicznego, społeczno-socjalnego. Właśnie wtedy, gdy rodzina nie może zadbać sama o siebie, potrzebna jest pomoc państwa, które oferuje profilaktykę i poradnictwo, podstawy stabilizacji i oparcia. W obszarze rządowych form wspomagających rodzinę znaczącą działalność w tym zakresie podejmują przedszkola, szkoły, poradnie, instytucje kuratora sądowego, domy pomocy społecznej, ośrodki pomocy rodzinie, Polski Czerwony Krzyż i inne.

Również szeroki wachlarz instytucji pozarządowych gwarantuje zaspokojenie podstawowych i niezbędnych potrzeb indywidualnych i społecznych, w atmosferze życzliwości, akceptacji i solidarności. Są to między innymi instytucje takie jak: stowarzyszenia, fundacje i ruchy społeczne. Przykładem może być działalność pozarządowych domów społecznych, Caritas, Fundacji Pomo-

cy Dzieciom, Fundacji Nasz Dom, ruchu oazowego Światło Życie itp. (Izdebska, 2001).

\section{Metodologiczne podstawy badań}

W niniejszym opracowaniu postanowiłam ukazać przekrojowy obraz stosunków rodzinnych we współczesnej Polsce i taki właśnie był cel moich badań. Praca zawiera zatem analizę tylko niektórych zagadnień spośród tych, które należą do psychologicznej problematyki rodziny. W rezultacie tego postanowienia powstały również cele bardziej szczegółowe, które można sformułować w postaci pytań badawczych:

1. Jakimi metodami wychowawczymi kierują się rodzice w wychowaniu swoich dzieci (w tym: system kar i nagród, stosunek rodziców do kar cielesnych, preferencje stylu kierowania wychowaniem)?

2. Jak można scharakteryzować relacje wewnątrzrodzinne między rodzicami a dziećmi, między obojgiem rodziców, więzi łączące członków rodziny?

3. Jaka jest przyszłość rodziny współczesnej?

4. Jaka jest rola mediów w rodzinie, częstotliwość oglądania telewizji i jaki wpływ wywiera ona na poszczególnych członków rodziny?

5. W jaki sposób współczesna rodzina spędza czas wolny, święta, weekendy?

6. Czy ankietowani uważają się za szczęśliwych i spełnionych w swojej rodzinie? 
Badania realizowane były w Zduńskiej Woli na próbie liczącej 30 rodzin. Przeprowadzono je w kilku dzielnicach miasta, w środowisku małego miasteczka, które posiada swoją specyfikę odróżniającą je od innych środowisk.

Badaniami objęto rodziców w wieku 27 - 46 lat. Badana zbiorowość odznaczała się określoną strukturą społeczno - demograficzną. Ogółem w badaniach uczestniczyło 21 kobiet i 9 mężczyzn. Wśród respondentów najwięcej było osób ze średnim wykształceniem - 14 osób, w drugiej kolejności z zawodowym - 10 osób, a najmniej z wyższym - 6 osób. Jeśli chodzi o strukturę zawodową to 8 osób stanowili pracownicy umysłowi, 7 osób to pracownicy umysłowo-fizyczni, 6 ankietowanych było pracownikami fizycznymi, 3 osoby to rzemieślnicy, a 6 respondentów to osoby bezrobotne. Przeważała rodzina małodzietna. Najczęściej posiadano dwoje dzieci - 11 rodzin, drugie miejsce w kolejności zajmowali rodzice $\mathrm{z}$ jednym dzieckiem - 10 rodzin, troje dzieci posiadało 6 rodzin, 2 rodziny - czworo dzieci i jedna rodzina siedmioro. Sytuacja ekonomiczna 14 rodzin uchodziła za trudną według zeznań respondentów. Tylko 2 osoby stwierdziły, że swoją sytuację materialną uważają za bardzo dobra, 6 rodzin przyznało się do tego, iż żyje na granicy ubóstwa, a 8 rodzin określiło swoją sytuację materialną jako ,średnią”.

Narzędziami zastosowanymi w badaniach były: ankieta własna oraz arkusz obserwacyjny.

Pytania właściwe ankiety dotyczyły zasadniczego przedmiotu badań ankietowanych. Dlatego też poruszyły one następujące problemy:

- rozumienie i pojmowanie przez rodziców terminu wychowania;

- metody wychowawcze stosowane w stosunku do dzieci;

- system nagród i kar wykorzystywanych przez rodziców, w tym stosunku do kar cielesnych;

- style wychowawcze;

- uczestnictwo ojca i matki w wychowaniu;

- potrzeby dziecka;

- sytuacja materialna rodziny;

- podział ról oraz więzi łączących członków rodziny;

- umiejętność radzenia sobie z kłopotami wynikającymi z życia codziennego;

- przyszłość rodziny i przyszłość dzieci;

- wartości, jakie rodzice pragną przekazać swoim dzieciom;

- rola mediów, w tym telewizji w rodzinie;

- „pogoń za pieniądzem” we współczesnym świecie;

- różnorodne formy spędzania wolnego czasu, świąt, weekendów w rodzinie;

- opinia na temat szczęścia w swojej rodzinie;

Tekst ankiety został wydrukowany i powielony w 40 egzemplarzach, z czego zwrotnie otrzymano 34 . Cztery ankiety powróciły puste. 
Ankieta została rozdana rodzicom uczniów klasy pierwszej szkoły podstawowej.

Natomiast obserwację rodzin przeprowadzono przez okres jednego miesiąca. Mając świadomość, że obserwacje tak krótkotrwałe nie wystarczają do dokładnego poznania zjawiska, oparte zaś na nich wnioski nie są zazwyczaj należycie uzasadnione lub też zawierają przedwczesne uzasadnienia, uznano, że zebrany materiał pozwoli bliżej przyjrzeć się współczesnej rodzinie i wysnuć wnioski dotyczące naszego współistnienia we wspólnocie rodzinnej.

\section{Analiza i interpretacja wyników badań}

Zadania wychowawcze współczesnej rodziny są o wiele trudniejsze niż rodziny rozumianej jako tradycyjna - żyjącej w poprzednich uwarunkowaniach społeczno - politycznych. Proces wychowania w rodzinie często bywa żywiołowy, spontaniczny, chaotyczny i nieprzemyślany. Zdarzają się jednak i teraz sytuacje, gdy rodzice stawiają na dziecko i na jego przyszłość, stosując świadome i celowe metody kształtujące młodego, dobrego człowieka.

Wyniki badań poddane zostały analizie jakościowej. W jej efekcie zaobserwowano szereg prawidłowości, wyodrębniono szereg wniosków pomocnych w odpowiedzi na postawione wcześniej pytania badawcze.

\section{Wychowanie}

Do najważniejszych czynników tkwiących w środowisku rodzinnym, które zapewnia prawidłowy rozwój i wychowanie dziecka, należy świadomość wychowawcza rodziców. Tej właśnie świadomości poświęcono kilka pytań ankiety. Pierwsze z nich dotyczyło rozumienia przez rodziców terminu „wychowanie”.

Okazało się, że ankietowani rodzice uważają, że wychowanie to:

1) sposób postępowania, cykl mający na celu przekazanie dziecku nawyków, zasad zachowania i postępowania;

2) przygotowanie do życia i nauka, także wpajanie wartości moralnych;

3) zapewnienie odpowiednich warunków dla prawidłowego rozwoju dziecka, zaspokajanie jego potrzeb;

4) przygotowanie dziecka do samodzielnego, późniejszego życia;

5) uczenie samodzielności w myśleniu, umiejętności życia w społeczeństwie, wybaczenia i szacunku dla drugiego człowieka;

6) nauka w tradycjach, dobrych manierach i kulturze;

7) wspieranie;

8) sztuka przekazywania miłości i umiejętność akceptacji dziecka z jego zaletami, jak również wadami.

Pojawiły się także wypowiedzi świadczące o dużej wiedzy pedagogicznej rodziców, być może z racji wykonywanego przez nich zawodu czy wykształ- 
cenia (nauczyciel, właściciel dobrze prosperującej firmy, pracownik socjalny). Stwierdzili oni, że wychowywać to:

1) rozumnie wprowadzić dziecko w otaczający je świat;

2) rozwijać jego cechy osobowości;

3) zaspokajać potrzeby biologiczne i psychiczne;

4) nadawać właściwy kierunek jego aktywności życiowej;

5) wybierać bodźce zewnętrzne wpływające na dziecko.

Z badań wynika, że rodzice najczęściej w swym systemie wychowawczym realizują wychowanie przez przykład, a wiadomo, iż ten sposób wychowania ma szczególną wartość, gdyż dziecko naśladuje osoby znaczące dla niego - przede wszystkim ojca i matkę. Opiekunowie dziecka świadomie bardzo często organizują różnego rodzaju zabawy w celu stymulacji rozwoju. Powszechnie uważają bowiem, że zabawa jest doskonałą nauką i metodą wychowywania młodego człowieka.

\section{Metody wychowawcze}

„Metody wychowawcze” stosowane przez ankietowanych rodziców to:

1) system kar i nagród;

2) rozmowa;

3) nakazy i zakazy;

4) thumaczenie;

5) konsekwencja w postępowaniu i stanowczość.

Najczęściej jednak w wypowiedziach pojawia się nagroda i kara jako najskuteczniejsza z metod. Rodzice uważają zgodnie, że stosowana nagroda jest bodźcem wzmacniającym postępowanie pozytywne, zachęcającym dziecko np. do wykonania porządku na biurku czy tornistrze, znajdująca wysokie uznanie w rodzinie. Bardzo częstą nagrodą jest wyrażenie aprobaty tzn. pochwała wyrażana w postaci ustnej, zadowolenia, pocałunku, uśmiechu czy przytulenia. Ten rodzaj nagrody stosują w znakomitej większości badani rodzice. Drugą z najczęściej stosowanych nagród, są nagrody rzeczowe w postaci słodyczy, upominków, prezentów, książek lub zabawek. Jak wiemy, z pedagogicznego punktu widzenia, takie nagrody mają niepożądany wpływ na dziecko. To nie wartość nagrody materialnej ma decydować o jej znaczeniu, ale pozytywna opinia i uznanie, których nagroda jest wyrazem. Zdarza się również, że dzieci są nagradzane pieniędzmi, choć nagrody pieniężne stanowią najmniejszy odsetek i jak można się domyśleć są wysoce niepedagogiczne.

Drugą metodą oddziaływań stosowaną przez ankietowanych rodziców jest „kara”. Problemu tego dotyczyły dwa pytania w ankiecie. Chodziło o ogólne spostrzeżenia na temat kary, powodu jej stosowania i stosunku do kar cielesnych.

$\mathrm{Z}$ pedagogicznego punktu widzenia kary są mniej skuteczne niż nagrody. Istnieją jednak takie sytuacje, w których zastosowanie kary jest czynnością niezbędną. 
Wśród stosowanych kar rodzice najczęściej wymieniają:

1) karę słowną;

2) krytykowanie dziecka wobec innych osób;

3) stosowanie krzyku;

4) poniżanie godności dziecka poprzez różnego rodzaju wyzwiska i przezywanie dziecka;

5) kary cielesne.

Większość z wymienionych wyżej kar należy do działań niepedagogicznych, stąd też ich oddziaływanie w wychowaniu dzieci jest mało skuteczne. Jednakże są one, jak wynika z badań, zbyt często stosowane.

Stosunek rodziców do kar cielesnych jest w większości przypadków zdecydowanie negatywny. Zastanawia jednak fakt, iż następnie ci sami rodzice przyznają się do częstego przysłowiowego klapsa i uważaja, że w niektórych sytuacjach jest on niezbędny. Przykładem niech będzie wypowiedź jednej z mam: ,jestem absolutnie przeciwna, choć czasem puszczają mi nerwy i dziecko dostaje klapsa w pupę".

Z przeprowadzonych badań wynika, że rodzice często stosują również kary, które można uznać za pedagogiczne, nie uwłaczające godności dziecka. Należą do nich przede wszystkim: tłumaczenie, zakazy, nakazy, kary w postaci wyrażania smutku, zawodu. Ten rodzaj kar stosuje niespełna połowa badanych rodziców.

\section{Systemy wychowania}

Kolejnym problemem poruszanym w ankiecie było pytanie o style wychowania: styl autokratyczny, styl demokratyczny, styl liberalny i prośba o ustosunkowanie się rodziców do najbardziej im bliskiego. Okazuje się, że zdecydowana większość opowiedziała się za stylem demokratycznym, a więc za partnerstwem, nienarzucaniem własnego zdania, posługiwaniem się językiem nagród, utrwalaniem więzi emocjonalnych, co w rezultacie prowadzi do podniesienia odpowiedzialności i samodzielności wychowanka. Swój wybór motywowali między innymi tym, iż w takiej rodzinie dzieci czują się bezpiecznie, mają zaufanie do rodziców; styl demokratyczny pozwoli dziecku w przyszłości być pewnym swoich decyzji, nauczy podejmowania trafnych wyborów i bycia odpowiedzialnym człowiekiem.

Jednakże znalazł się również mały procent rodziców, którzy upodobali sobie styl autokratyczny, czyli wyraźny podział na kierujących i kierowanych, narzucanie własnego zdania, niedopuszczanie dzieci do udziału w podejmowaniu decyzji. Wychowanie to przesadnie ogranicza swobodę dziecka, co w rozumieniu jednego $\mathrm{z}$ ankietowanych wpływa na utrzymanie większej dyscypliny i tym samym jest jedną z metod wychowania.

Również styl liberalny stał się bliski stylowi wychowania dziecka kilku rodziców, co jest niemałym zaskoczeniem. Rodzice ci pozostawiają dziecku cał- 
kowitą swobodę, zgadzają się na spełnianie wszystkich jego żądań. Darzą swe dziecko zbyt dużym uczuciem, nie widząc wad w swym postępowaniu.

\section{Podział ról rodzicielskich}

Analizując strukturę podziału ról w rodzinie oraz stosunek respondentów do niektórych obowiązków domowo-wychowawczych, pytano o podział ról rodzicielskich. W rodzinie współczesnej uwidocznia się tendencja dążenia do partnerstwa w wyżej wymienionej kwestii. Doświadczenia życia codziennego wskazują jednak, iż powyższe dążenia pozostają częściej w sferze postulatów niż rzeczywistych zachowań. Okazało się bowiem, że zdaniem większości respondentów odpowiedzialni za wychowanie powinni być na równi matka i ojciec. Jednakże następne wypowiedzi świadczą o tym, że w przeważającej liczbie przypadków to właśnie matka zajmuje się wychowaniem dzieci, a tylko w nielicznych rodzinach obowiązki te wspólnie wypełniają ojcowie i matki. I tak, w przypadku udziału w wywiadówkach szkolnych, zakupach odzieży, wizyt lekarskich, obciążane są matki, udział ojców występuje mniej więcej w co trzeciej rodzinie.

Wyniki badań dowodzą, że matki w większym stopniu niż ojcowie współdziałają ze szkołą i nauczycielem. Częściej też uczestniczą w spotkaniach indywidualnych. Z obserwacji wynika, że ojcowie kontaktują się ze szkołą bądź nauczycielem rzadziej niż raz w miesiącu. Matki natomiast w większości często lub bardzo często spotykają się z nauczycielem, omawiając najważniejsze problemy wychowawcze oraz sukcesy i porażki dziecka. Niepokojący jest fakt, iż mały procent ojców bierze udział w zajęciach otwartych organizowanych przez szkołę, gdy tymczasem matki uczestniczą w tej formie współdziałania bardzo licznie. W zebraniach organizowanych przez szkołę uczestniczy również więcej matek niż ojców. Są także tacy rodzice, którzy nie biorą udziału w spotkaniach szkolnych.

W większości ankietowanych rodzin występuje równy podział obowiązków domowych. Zaznacza się tutaj czynny i codzienny udział ojca w przygotowywaniu posiłków, zakupach, sprzątaniu. Zdarzają się jednak również takie rodziny gdzie obowiązkami tymi jest obciążona jedynie żona. Biorąc pod uwagę fakt, iż bardzo często kobiety pracujące zawodowo są w domu obarczane przez męża „drugim, dodatkowym etatem”, należy podkreślić, że współczesna rzeczywistość wymusza na nich umiejętność godzenia ze sobą tych wszystkich obowiązków, urabiając je na wzór kobiet zaradnych i przedsiębiorczych, radzących sobie w dzisiejszym świecie.

\section{Potrzeby dziecka}

Analizując potrzeby dzieci, należy stwierdzić, że większą ich znajomość wykazują rodzice z wyższym, a następnie ze średnim wykształceniem. Badane 
matki trafnie rozgraniczają, znają i zaspokajają potrzeby swoich dzieci. Część rodziców nie jest w stanie w pełni zaspokoić potrzeb dziecięcych, głównie z powodu braku środków finansowych. W większości przypadków rodzice realizują potrzeby dzieci w stopniu podstawowym oraz te, które są najbardziej konieczne dla życia, np. jedzenie, ubranie, zabawki. Natomiast potrzeby psychiczne takie jak: potrzeba kontaktu emocjonalnego z dzieckiem, uznania i akceptacji dziecka, przynależności i miłości, w większości przypadków zaspokajają matki. Część ojców, która wypełniała ankietę, odczuwa trudność w kontakcie z dzieckiem ze względu na brak czasu i pracę zawodową.

Natomiast na pytanie o częstotliwość rozmów przeprowadzanych z dzieckiem, zdecydowana większość rodziców odpowiedziała: „codziennie”.

\section{Sytuacja materialna i ekonomiczna rodziny}

Ważnym czynnikiem prawidłowego funkcjonowania rodziny są jej zasoby finansowe. Właśnie tego problemu dotyczyło kolejne pytanie. Środki finansowe rodziny pochodzą najczęściej $\mathrm{u}$ ankietowanych $\mathrm{z}$ wynagrodzenia za pracę, z działalności własnych firm zarówno produkcyjnych, usługowych, jak i handlowych. Sytuacja finansowa rodziny zależy głównie od wysokości dochodów, które wiążą się z liczbą osób pracujących, a także z wykształceniem i miejscem pracy oraz liczbą osób, które utrzymują się z uzyskanego budżetu domowego. Analiza przeprowadzonych badań ujawnia zróżnicowaną sytuację finansową. Rodzice o bardzo dobrej sytuacji materialnej stwierdzali: „Spełniam każdą potrzebę swego dziecka, posiada ono dużo zabawek i wszelkich niezbędnych mu rzeczy. Obawiamy się jednak, by nadmiar kupowanych artykułów nie spowodował wypaczenia osobowości dziecka”. „Rozpieszczamy dziecko różnymi zakupami, dlatego też przestało ono mieć granice zachcianek i wymagań. Nie skutkują już zakazy i nasze prośby do dziecka". Wypowiedzi te dowodzą, że bardzo dobre warunki materialne rodziny nie zawsze pozytywnie wpływają na rozwój dziecka.

Diametralnie różne były wypowiedzi rodziców z grupy funkcjonującej poniżej minimum socjalnego: „Nie mogę spełnić prośby dziecka dotyczącej zakupu zabawki, gdyż nie stać mnie na zaspokojenie podstawowych potrzeb”. „W mojej rodzinie muszę się bardzo ograniczać w wydatkach. Brakuje mi pieniędzy i dlatego nie mogę kupić dziecku często nawet słodyczy".

Większość badanych mimo trudnej sytuacji materialnej, ograniczając własne wydatki dla siebie, stara się zapewnić dziecku potrzebne do prawidłowego rozwoju wyżywienie i ubranie. Nie żałuje też pieniędzy na drobne i mało kosztowne zabawki.

Wiele $\mathrm{z}$ ankietowanych rodzin żyje $\mathrm{w}$ trudnych bądź bardzo trudnych warunkach materialnych. Mają kłopoty finansowe, mieszkaniowe, konsumpcyjne, które bardzo często nie pozwalają na zaspokojenie podstawowych potrzeb biologicznych, materialnych i psychicznych dziecka. Życie niektórych rodzin egzystu- 
jących w ubóstwie materialnym stało się źródłem ciagłych stresów jej członków, powoduje też zobojętnienie na problemy opiekuńcze swoich dzieci.

Opisując więzi łączące poszczególnych członków rodziny, ankietowani najczęściej wymieniali: miłość, zrozumienie, zaufanie, tolerancję. W związku z tym nasuwa się wniosek, iż badani żyją w takich rodzinach bądź ku takiej właśnie rodzinie dążą.

Przykładem może być wypowiedź jednej z mam: „Wydaje mi się, że jesteśmy szczęśliwą, kochającą się rodziną. Jako rodzice jesteśmy z mężem autorytetami dla dzieci, choć każde na innym polu. Przed mężem dzieci czują większy respekt, być może z racji tego, że bardzo dużo pracuje. Do mnie zwracają się z każdym problemem i kłopotem. Dzieci również bardzo się kochają i pomimo to, że czasami dochodzi między nimi do sprzeczek, „skoczyłyby za sobą w ogień”.

\section{Trudności życiowe}

Ankietowani odpowiadali również na pytanie dotyczące umiejętności radzenia sobie z trudnościami wynikającymi z życia codziennego. Okazuje się, iż większość respondentów stara się rozwiązywać problemy we własnej rodzinie, nie ujawniając ich dzieciom. Rozwiązuje je na bieżąco i stara się do nich nie dopuszczać. Są tacy rodzice, którzy na zadane pytanie odpowiadają: „Bardzo dobrze”. Są również tacy, którzy nie mają większych problemów: „My jako rodzina nie mamy kłopotów materialnych, dlatego też żyje nam się lepiej niż innym rodzinom". Wśród ankietowanych znalazły się także rodziny, które stwierdzają, iż problemy życia często je przerastają: „Chcielibyśmy dać dzieciom wszystko, lecz jest to coraz bardziej trudne". Kilka osób zwróciło w tym momencie uwagę na sytuację gospodarczą w naszym kraju, na trudności finansowe coraz większej liczby rodzin, na problem bezrobocia, mając pretensje i wyrażając swoją zdecydowaną dezaprobatę co do obecnej sytuacji.

\section{Przyszlość rodziny}

Kolejnym poruszanym problemem była przyszłość rodziny, dzieci. Ciekawi fakt, iż najczęściej przyszłość dzieci postrzegana była przez rodziców w jasnych barwach. Nie stroniono oczywiście od wypowiedzi pesymistycznych typu: „Dzisiaj widzę przyszłość w czarnych kolorach, ale nadzieja na lepsze jutro jest motorem napędowym do dalszego życia". Natomiast na podstawie chociażby wyżej wymienionego przykładu można stwierdzić, że nie brakuje rodzinom wiary na lepsze i godniejsze życie.

Z badań wynika również, że duża grupa rodziców żyje dniem dzisiejszym, nie troszcząc się o przyszłość, nie myśląc o niej. Być może wynika to z trudnej sytuacji gospodarczej panującej w naszym kraju, a być może z tego, iż niektóre rodziny „korzystają” z przywilejów i przyjemności teraźniejszego życia, wykazując w ten sposób brak odpowiedzialności i troski o przyszłość swoich dzieci. 


\section{Najważniejsze wartości}

Wartościami, jakie rodzice chcieliby przekazać swoim dzieciom, są najczęściej wartości konsumpcyjne, intelektualne oraz kulturowe. Stosunkowo mało ankietowanych wymienia wartości religijne. Matki częściej kładą nacisk na kształtowanie postaw, wartości rodzinne, kulturowe, natomiast ojcowie przywiązują wagę do obowiązkowości, samorealizacji oraz szacunku do pracy, zdyscyplinowania, odwagi i sprawiedliwości. Ponadto rodzice chcieliby również przekazać wartości: miłości, szacunku do starszych, szanowania tradycji, wrażliwości na ludzką krzywdę, bezinteresowności, uczciwości. Wielu rodzicom bliski jest również problem tolerancji, pragnęliby wykształcić u swoich dzieci taką postawę i umiejętność uznawania prawa każdego człowieka do własnego zdania.

\section{Rola telewizji i mediów}

Analizując rolę telewizji i mediów w rodzinie, należy stwierdzić, że rodzice w większości przypadków są zdania, iż telewizja wpływa antypedagogicznie na dzieci i nie powinna być nadużywana. Ponadto powtarza się stwierdzenie - „telewizja jest złodziejem czasu". Niektórzy rodzice przyznają się do tego, że w ich domu ogląda się bardzo dużo różnego rodzaju programów, zdając sobie jednocześnie sprawę z faktu, iż bardzo często nie są to pozycje przeznaczone dla dzieci.

Są również tacy, którzy uważają, że odbiór emitowanych przez telewizję programów może być wykorzystany przez rodziców jako narzędzie wychowawcze. Niezbędna jest jednak w tym wypadku kontrola rodziców nie tylko czasu odbioru telewizji, ale i treści oglądanych przez dzieci oraz ukierunkowanie ich odbioru, między innymi przez rozmowy w gronie rodzinnym.

W większości ankietowani są zdania, że telewizja jest nierozerwalnie związana z codziennym życiem rodziny, jest centralną i integralną częścią rodzinnodomowego życia, stając się najpopularniejszym domowym środkiem przekazywania informacji, wiedzy, rozrywki, uczestnictwa w kulturze, towarzyszy ona rodzinie w dni powszednie i świąteczne, wypełniając im czas wolny, a także czas różnych zajęć i prac domowych.

W kilku z badanych rodzin telewizja nie odgrywa żadnej roli, tak przynajmniej twierdzą respondenci.

\section{Pogoń za pieniądzem}

Następnym rozważaniom poddane zostało zjawisko pogoni za pieniądzem we współczesnej rodzinie. W wielu rodzinach rodzice pracują po wiele godzin, aby zapewnić swym członkom godne utrzymanie, poświęcając czas i siły, które 
mogliby przeznaczyć dla umacniania więzi w rodzinie. W rezultacie prowadzi to do nieporozumień, konfliktów i wielu nieprzyjemnych zdarzeń zagrażających rodzinnej wspólnocie. Rodzice podzielają zdanie na temat braku czasu i ciagłej walce o każdy grosz. Zgodnie stwierdzają że pieniądze nie dają szczęścia, ale ich brak uniemożliwia godne życie. Przykładem niech będzie wypowiedź jednego z ojców: „W Polsce ludzie ciężko pracują, aby przeżyć. Jeśli ktoś pracuje osiem godzin za marne grosze i dorabia po godzinach kosztem życia rodzinnego, aby żona nie kupowała ubrań tylko w „lumpeksie”, lub jeśli ktoś jest np. kierowcą i całe dnie nie ma go w domu, to nie jest to pogoń za pieniądzem, jest to pogoń za chlebem i za godnością".

Padają również sądy, że pogoń za pieniądzem wynika z chęci lepszego życia, umożliwienia dzieciom zdobywania wszechstronnej wiedzy, zapewnienia im lepszej przyszłości. U wielu ankietowanych nasuwa się refleksja utraty kontaktów z dziećmi, małżonkiem poprzez ciagłą chęć zaspokajania potrzeb materialnych, co w rezultacie prowadzi do degradacji życia rodzinnego. Poważnym problemem staje się rekompensowanie dzieciom braku czasu dla nich kupnem zabawek, gier itp., co nie zastępuje uczucia miłości i czułości.

Są również rodzice, którzy nie mają problemów materialnych. W tym przypadku próbują uchronić swoje dzieci przed wywyższaniem się z powodu posiadania pieniędzy. Dla wielu bowiem rodzin w dzisiejszych czasach ważniejsze jest „mieć” niż „być” i nie zważają one na to, jak wielkim zagrożeniem jest nieumiejętne wychowanie, niewłaściwy, konsumpcyjny stosunek do życia. Osiaganie dóbr materialnych stanowi dla niektórych rodzin treść i cel życia, dla innych ważne jest zdrowie i szczęście.

Niezaprzeczalny jest jednak fakt, iż pieniądze są do życia niezbędne. Pozostaje jedynie nadzieja, że sytuacja w naszym kraju poprawi się, społeczeństwo będzie godziwie wynagradzane za swoją pracę, co polepszy relacje rodzinne i przysporzy Polakom więcej radości i optymistycznego spojrzenia w przyszłość.

\section{Formy spędzania czasu wolnego}

Formy spędzania czasu wolnego, świąt, weekendów to kolejny problem poddany analizie ankietowanych. Wynika z niej, że do najczęstszych form należą: spacery, wycieczki, film i lektura. Zastanawia fakt, że mały procent rodziców wymienia komputer, jak również muzykę. Dla większości badanych dom jest najczęściej miejscem wypoczynku i rozrywki, co wskazuje na charakterystyczny domowy tryb życia. Dominuje również korzystanie ze środków masowego przekazu, a także spotkania towarzyskie. Spacery i wycieczki uzależnione są od pory roku. Podróże są popularne $\mathrm{w}$ rodzinach posiadających samochód, a przebywanie na powietrzu odbywa się częściej w okresie wiosenno-letnim. W wielu rodzinach spacer wiąże się z codziennymi zakupami. Jest to świadomie realizowana forma wypoczynku, częściej występująca w tych rodzinach, w których są 
dzieci przedszkolne i młodsze. Dla większości rodzin stałym sposobem spędzania czasu jest rodzinny spacer niedzielny. Subiektywne odczucie braku czasu, a także formy jego użytkowania znajdują odzwierciedlenie w tym, że za czas wolny rodziny uważają także ten, który poświęcają na wykonywanie prac na rzecz rodziny, takich jak: majsterkowanie, prace w ogródku, pomoc w lekcjach, wyjście z dziećmi po zakupy czy w celu załatwienia jakichś spraw rodzinnych. Rodzice podkreślają tu zwłaszcza potrzebę przebywania razem z dziećmi. Takie wspólne wyjścia z domu stwarzają okazję do rozmowy o przebiegu dnia i jego problemach. Rodzice łączą tu więc sprawy wychowawcze ze sprawami związanymi z funkcjonowaniem domu.

Istotne $\mathrm{z}$ wychowawczego punktu widzenia jest spędzanie czasu urlopowego, wakacyjnego. Charakterystyczne jest zjawisko dzielenia urlopu w ten sposób, by przynajmniej jeden miesiąc któreś z rodziców mogło być z dziećmi. Analiza wymienionego problemu na przykładach konkretnych rodzin pozwala wysunąć przypuszczenie, iż ten sposób urlopowania stanowi nie tylko wypoczynek, lecz jest rekompensatą niedoborów w kontaktach z dziećmi.

Wypoczynek rodzinny poprzez różne formy i sposoby jego wykorzystywania może stwarzać możliwość wychowawczego oddziaływania, rozwoju i edukacji dziecka, ale także integracji rodziny. Istnieje bowiem wiele wspólnych momentów w czasie wolnym, ważnych dla jej integracji. Wspólne przebywanie ze sobą, konsumpcja dóbr kultury mogą sprzyjać kształtowaniu się kontaktów między członkami rodziny, utrwalaniu wzajemnych stosunków między dziećmi i rodzicami.

Święta ankietowani najczęściej spędzają w sposób tradycyjny: w gronie bliższej i dalszej rodziny. Nieliczni wyjeżdżają, także w celu odpoczynku od codzienności, zaznajomienia się z obrządkami świątecznymi w danym regionie Polski.

\section{Typowy dzień polskiej rodziny}

Typowy dzień tradycyjnej polskiej rodziny wygląda bardzo szaro. Z analizy wynika, że rodzice pochłonięci praca, codzienną domową krzątaniną nie mają zbyt wiele czasu na wzajemne rozmowy, kontakty, zabawy z dziećmi. Dowodem niech będzie wypowiedź kobiety z wyższym wykształceniem, zajmującej się prowadzeniem domu: „Wstaję o 6.30, następnie szykuję śniadanie, które zjadamy wszyscy razem. Mąż odwozi młodszą córkę do szkoły. Starsze dziecko chodzi do szkoły po południu, dlatego też do południa odrabiam z nim lekcje, ponieważ często potrzebna jest mu moja pomoc. Około południa odbieram młodszą córkę ze szkoły i zawożę na lekcje syna. W międzyczasie robię zakupy. Po powrocie do domu gotuję obiad, który każdy z domowników je o innej porze. Po południu zawożę dzieci na zajęcia dodatkowe. Wracamy do domu około godziny 19.00. W dni powszednie nie ma w naszym domu typowej kolacji. Następnie córka odrabia lekcje, które muszę skontrolować. Dzieci kładą się spać ok. 21.30. 
Mąż bardzo dużo pracuje i wraca do domu późnym wieczorem. Po całodziennej krzątaninie jestem już zbyt zmęczona, by mu towarzyszyć, jednak staram się jak mogę, by nie zatracić wzajemnego kontaktu. Pocieszeniem są dla mnie soboty i niedziele, wtedy spędzamy wspólnie z dziećmi bardzo dużo czasu i to jest mój odpoczynek".

\section{Szczęście w rodzinie}

Ostatnie pytanie do ankietowanych dotyczyło szczęścia w rodzinie. Większość rodziców zgodnie stwierdziła, że żyje w szczęśliwej rodzinie. Odpowiedzi były jednoznaczne, mimo że bardzo często respondenci zwracali uwagę na trudną sytuację finansową. Na szczęście w rodzinie składa się wszystko, co służy jej rozwojowi, wywołuje pozytywne stany psychiczne, jest źródłem zadowolenia z własnej sytuacji - tak twierdzą ankietowani.

Siedemnastowieczny moralista hiszpański Baltazar Gracjan twierdził, że „trzeba mieć zawsze coś do pragnienia, aby nie być nieszczęśliwym w swym szczęściu" (Izdebska, 1988). To bardzo mądre słowa wskazujące na ciągłą potrzebę pragnienia szczęścia w życiu człowieka. Wydawać by się mogło, że owo pragnienie już jest szczęściem, bo kiedy osiągniemy cel, czujemy chwilową satysfakcję, a później pustkę i próbujemy znów do czegoś dążyć. Tak również jest w przypadku rodziny, dla której szczęście to szereg drobnych radości każdego dnia. To zadowolenie $\mathrm{z}$ tego, że jesteśmy zdrowi, że osiagamy w swoim życiu coraz to nowe cele. Szczęście rodziny zdaniem jednego z rodziców to: „zdrowie dzieci, wzajemne zrozumienie, poczucie bezpieczeństwa, umiejętność rozmawiania ze sobą, własny dom, praca".

Nasuwa się wniosek, że mimo trudu, z jakim przychodzi żyć niektórym rodzinom („nie wypada mi na tę kartkę płakać, dlatego napiszę, że cieszy mnie to, że w naszej rodzinie możemy na siebie liczyć...”) większość jest świadoma szczęścia, którego doświadcza w życiu, szczęścia, za które są wdzięczni Bogu czy losowi. Pocieszający jest fakt, że ankietowani potrafią dostrzec szczęście i cieszyć się tym, co mają, pomimo tego, że bardzo często jest im ciężko - jak to w życiu.

\section{Wnioski}

Podsumowując wyniki badań, należy stwierdzić, że:

- Wychowanie to dla ankietowanych przede wszystkim przygotowanie do przyszłego życia, zapewnienie odpowiednich warunków do prawidłowego rozwoju dziecka oraz przekazanie najważniejszych wartości wyznawanych przez rodziców. 
- Najpopularniejszą metodą wychowawczą stosowaną przez rodziców jest rozmowa z dzieckiem.

- Wszyscy respondenci nagradzają i karzą swoje dzieci. Do najczęściej stosowanych nagród należą: pochwała ustna, nagroda rzeczowa w postaci słodyczy lub zabawek, nagroda pieniężna. W większości przypadków rodzice nie stronią od kar, w tym kar cielesnych, występujących najczęściej w postaci klapsów. Paradoksem jest fakt, iż ci sami ankietowani wyrażają swój zdecydowanie negatywny stosunek do kar cielesnych.

- Styl demokratyczny jest tym stylem kierowania wychowaniem, z którym identyfikuje się większość rodziców.

- Matka jest tą osobą która bardziej uczestniczy w wychowaniu dzieci, w związku z tym, iż nadal w większości rodzin ojciec zarabia na utrzymanie domu.

- Przeważająca ilość problemów dotykających dzieci to problemy szkolne oraz związane z kontaktami koleżeńskimi.

- Najczęstsze potrzeby dzieci to: potrzeba miłości, kontaktu emocjonalnego, uznania i akceptacji. Zdecydowana większość rodziców rozmawia codziennie ze swoim dzieckiem o jego problemach i potrzebach.

- Pozycja ekonomiczna ankietowanych rodzin jest zróżnicowana. Jednak silniejszą grupę stanowią rodziny, które wskazują na swoją słabą kondycję finansową.

- Miłość, zrozumienie, tolerancja i zaufanie to podstawa więzi łączącej członków rodziny.

- Badani starają się sami rozwiązywać problemy związane z codziennym życiem. Nieliczni zwracają się o pomoc do najbliższych.

- Większość rodziców żyje dniem codziennym, nie troszcząc się zbytnio o przyszłość w związku z trudną sytuacją gospodarczą. Jednak pragną dla swoich dzieci przede wszystkim lepszego jutra i godniejszego życia. W związku z tym starają się przekazać im podstawowe wartości, jakie uważają za najważniejsze, tj. miłość, szacunek, uczciwość, poszanowanie tradycji.

- Telewizja, jak wynika z ankiety, nie wpływa wychowawczo na dzieci, jak również nie powinna być nadużywana. Jednocześnie wszyscy zgodnie stwierdzają, że zbyt dużo czasu poświęca się w rodzinach na oglądanie telewizji.

- Ankietowani zgodnie stwierdzają, że pogoń za pieniądzem zdominowała dzisiejsze życie, bardzo często tylko dlatego, że wielu rodzicom nie wystarcza pieniędzy na zaspokojenie podstawowych potrzeb i zmuszeni są do szukania dodatkowych zajęć.

- Do najczęstszych form spędzania wolnego czasu należą: spacery, wycieczki, film i lektura. Wakacje oraz urlopy starają się rodziny spędzać razem, nadrabiając $\mathrm{w}$ ten sposób niedobory w kontaktach z dziećmi i rekompen- 
sując im cały rok pracy. Święta natomiast spędzane są w sposób tradycyjny, tj. w gronie najbliższej rodziny.

- Typowy dzień polskiej rodziny współczesnej wygląda bardzo szaro. Respondenci w całości pochłonięci codzienną krzątaniną nie mają zbyt wiele czasu na rozmowy i zabawy z dziećmi.

- Wszyscy zgodnie stwierdzają, iż mimo trudu i znoju codziennego życia, uważają się za szczęśliwych oraz uważają, że mają szczęśliwe rodziny. Bogatszym brakuje czasu, biedniejszym - pieniędzy, jednak zdają sobie sprawę ze szczęścia, jakiego doświadczają w swoim życiu i są wdzięczni losowi za to, co mają.

Ojciec Święty Jan Paweł II powiedział kiedyś, że każde społeczeństwo powinno mieć swoje Westerplatte, swoje podstawowe wartości, których winno bronić do końca. Wydaje się, że nadszedł czas, by współczesnym Westerplatte dla polskiego społeczeństwa stała się właśnie rodzina, by upowszechnić te wartości i czynniki, które stanowią dobrą rodzinę, umacniają ją i wszechstronnie rozwijają.

Wszyscy, którzy mają jakiś wpływ na współczesny obraz polskiej rodziny: politycy, prawnicy i urzędnicy, nauczyciele i pedagodzy, lekarze, duchowni, filozofowie, twórcy kultury, uczeni i dziennikarze, wszyscy, którym leży na sercu los i rozwój polskiego społeczeństwa, winni podjąć wszelkie dostępne im działania dla wprowadzenia konsekwentnych działań prorodzinnych, dzięki którym polskiej rodzinie będzie żyło się lepiej i godniej.

\section{Bibliografia}

Badura-Madej W., Dobrzyńska-Masterhazy A. (2000). Przemoc w rodzinie. Interwencja kryzysowa i psychoterapia. Kraków: Wydawnictwo Uniwersytetu Jagiellońskiego.

Cudak, H. (2000). Funkcje rodziny w pierwszych okresach rozwojowych dziecka. Warszawa: Wyższa Szkoła Pedagogiczna Towarzystwa Wiedzy Powszechnej.

Danielewicz, W. T., Izdebska, J., Krzesińska-Żach, B. (2001). Pomoc dziecku w rodzinie i środowisku lokalnym. Białystok: Trans Humana.

Dymara, B. (1998). Dziecko w świecie rodziny. Szkice o wychowaniu. Kraków: Oficyna Wydawnicza IMPULS.

Izdebska, H. (1988). Szczęście dziecka. Warszawa: Instytut Wydawniczy Związków Zawodowych.

Izdebska, J. (2001). Rodzina dziecko telewizja. Białystok: Trans Humana.

Jakubiak, K. (red.), (1995). Rodzina jako środowisko wychowawcze w czasach Nowożytnych. Bydgoszcz: Wydawnictwo Wyższej Szkoły Pedagogicznej.

Kryczka, P. (red.), (1997). Rodzina w zmieniajacym się spoleczeństwie. Lublin. 


\section{Model of Life of Contemporary Family (Summary)}

From the time immorial the concept of family has been drawing attention of philosophers as well as reformers of society. Already Aristotle made attempts of theoretical analysis of family and its place in society. Both the Old and New Testament are full of images, comparisons, examples and moral advice concerning marriage and family life. Investigation of family life is in favour of treating family as a separate social group secures its biological continuity. The other factor is willingness of passing on the accumulated culture in order to maintain and save one's identity.

Family plays a major part in every person's life. It's recognized as an element of development. It should be a source of mutual love, respect and solidarity. However, nowadays a Polish family is to function in a very hard time. The foundations of system of values has been shaken even though it's been so arduously built through out centuries, the standard of living of many families has deteriorated, ethical and moral standards have loosen as well as emotional ties between family members.

The study presented hereby reveals sectional image of family relations in contemporary Poland which was the goal of my research. The work contains merely a few issues which belong psychological problems of family like understanding the term of upbringing by the parents; pedagogical methods; the system of rewards and punishments; pedagogical styles; participation of mother and father in upbringing the child; child's needs; material status of family; the division of roles and relations among family members; the ability of dealing with everydays' problems; the future family and the future of child; the values which parents wish to pass on to their children; the role of media within television in family life; the chase after the money in contemporary world; various ways of spending free time, holidays, weekends in family, the opinion on happiness in one's family.

The research has been carried out on a trial of 30 families. The tools used in the research are: survey and evaluation/observation sheet.

A qualitative analysis has been carried out on the outcome of the research. As a result a number of regularities is noticeable and helpful in development of the above issues. 